\title{
高断熱高気密住宅における熱環境特性と居住者の健康に関する調査 INVESTIGATION OF THERMAL PERFORMANCE AND OCCUPANT'S HEALTH
IN WELL-INSULATED AND AIRTIGHT HOUSES
}

\author{
吉 野 博*, 長谷川 兼一** \\ Hiroshi YOSHINO and Ken-ichi HASEGAWA
}

\begin{abstract}
The indoor thermal environment, air quality and occupant behavior in well-insulated and airtight houses in and around Tohoku district are investigated through questionnaire and field measurement. This report describes the results from the questionnaire survey conducted in summer of 1993 and winter of 1994, and thermal environment of 16 well-insulated and airtight houses in Morioka and Sendai by the field measurement in winter and summer of 1994. The number of houses investigated by the questionnaire survey is about 350 . The wellinsulated and airtight houses investigated have mechanical ventilation system and space heating system for a whole house. The main findings are as follows:

1. Indoor environment during the heating season of almost houses is thermally comfortable, compared with that of existing house in Japan.

2. The houses provide a comfortable indoor environment and also have a good influence on occupant' health. However, there are some problems related to dry feeling, which should be investigated in future.

3. During the summer, the room temperatures are stable compared with the change of the outdoor temperature in the day, but it doesn't decrease at night even if the outdoor temperature drops. It is possible to improve the indoor environment by cross ventilation with opening windows or night time ventilation.
\end{abstract}

Keywords: Well-insulated and airtight houses, Thermal environment, Occupants' health, Questionnaire survey, Field measurement

高断熱高気密住宅，熱環境，健康，アンケート調査，実測調查

\section{1 はじめに}

近年, 住宅においては快適性, 健康性に対するニーズが高まりつ つあり,一方では地球環境問題等から省エネルギーに対する要請も 強まっている。これらの要求を満足させるには, 断熱・気密化の推 進，自然エネルギー利用システムの導入などが必要であり，様々な 方面で方策が講じられている。例えば，建設省では現在の新省エネ ルギー基準よりもはるかに高い性能を目䟱とする次世代省エネル ギ一基準和 の策定を誘導基準として検討中である。

さて, 住宅を断熱気密化する必要性は, (1)省エネルギー, (2)室内 熱空気環境の質の向上，の 2 つの観点から述べることができる。ま ず，(1)は，断熱気密化により室内からの熱の流出が抑えられるた め, 室温を快適な範囲に保つために必要な暖冷房エネルギーを低減 させることが可能となる。しかし，暖房面積・援房時間の増大など により，必ずしも省エネルギーが達成されるとは限らないことが指 摘されており，断熱気密性能レベルとの関連で検討が必要となる。 次に; (2)は, 断熱気密化により輻射器境の向上と上下温度差の低減 が期待できるため, 温熱快適性が向上する。断熱性能を高めると空 ガラスなどの壁体表面温度が上昇するために, 冬期には冷輻射が低 減される。また, 気密性能を高めると冬期に隙間からの冷気の侵入 を防止でき,コールドドラフトや上下温度差の低減が実現可能とな
る。また, 壁体表面温度が空気温度に近づくため, 結露防止へも期 待でき, カビの発生を防ぐことにより室内空気を清浄に保つことが できる。住宅の断熱気密化は以上の観点からその有効性が期待でき るが, 実際の住宅において適用した場合の効果や問題点について明 確に把握されているとは言い難い。さらに，我が国では高断熱高気 密住宅そのものの歴史が浅いために, 設計基準が十分に整理されて いるとはいえない。このような状況においては, 室内空気污染の危 険性, ダニやカビによる居住者の健康への影響などが懸念されると ともに，省エネルギー性についても明らかではない。

そこで, 住宅を断熱気密化した場合に形成される熱空気環境の特 徵やそれに関わる問題点, 省エネルギー性を明らかにすることを目 的とし, 東北地方を中心として建設されている高断熱高気密住宅を 対象としたアンケート調查および実測調查を実施した。本論文で は, 高断熱高気密住宅の熱環境特性と居住者の健康について調査結 果を考察・分析したので報告する非。

\section{2 アンケート調查}

\section{1 調查の概要}

高断熱高気密住宅の選定に際して，現在建設されている住宅の中 から無作為に抽出することは困難であるために, 各工務店・施工業
* 東北大学大学院工学研究科 教授. 工妿

** 信州大学工学部社会開発工学科 助手・博上 (工学)
Prof., Dept. of Architecture and Building Science, Graduate School of Engineering, Tohoku Univ., Dr. Eng.

Research Assoc., Dept. of Architecture and Civil Eng., Faculty of Eng., Shinshu Univ., Dr. Eng. 
琵1 アンケート調查の内容

\begin{tabular}{|c|c|}
\hline 調査内容の分穎 & 質問項目 \\
\hline $\begin{array}{c}\text { 引っ越し前の住宅に } \\
\text { 関する質問 }\end{array}$ & $\begin{array}{l}\text { 床面皖, 構造, 住戸形態, 居間の空, } \\
\text { 使用暖房器具, 冬期の問題点, 发期の題点 }\end{array}$ \\
\hline シェルター性能 & 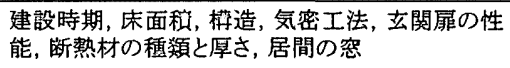 \\
\hline 設備 & 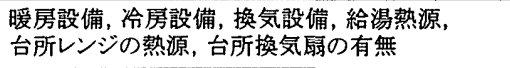 \\
\hline 住まい方 & $\begin{array}{l}\text { 暧冾房設備・換気設備の使用状況, 防棔の工夫, } \\
\text { 空気の污れの対処, 湿気の対処, 住まい方の変化 }\end{array}$ \\
\hline エネルギー消費居 & $\begin{array}{l}\text { 引っ越し前の住宅との比琝, } \\
\text { 月別のエネルキー消赛』 }\end{array}$ \\
\hline 居住者特性 & 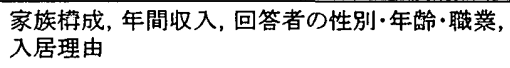 \\
\hline 問題点 & $\begin{array}{l}\text { 暑さ, 空気の污れ, 湿気, 結璐の有無, } \\
\text { 揵㞼の変化, 音 }\end{array}$ \\
\hline
\end{tabular}

品2 アンケート調查の対象地域と回收状況

\begin{tabular}{|c|c|c|c|c|}
\hline \multirow{2}{*}{\multicolumn{2}{|c|}{ 対象地域 }} & \multirow{2}{*}{ 配布敏 } & \multicolumn{2}{|c|}{ 回收数 } \\
\hline & & & 冬期 & 罗期 \\
\hline \multicolumn{2}{|c|}{ 北海道 } & 50 & 26 & 21 \\
\hline \multirow{6}{*}{ 東北地方 } & 青蝲 & 107 & 74 & 72 \\
\hline & 岩手 & 83 & 25 & 25 \\
\hline & 秋田 & 197 & 100 & 100 \\
\hline & 山形 & 41 & 16 & 14 \\
\hline & 宮城 & 158 & 44 & 43 \\
\hline & 福息 & 61 & 52 & 49 \\
\hline \multicolumn{2}{|c|}{ 北陸・長野 } & 122 & 67 & 52 \\
\hline \multicolumn{2}{|c|}{ その他 } & 99 & 42 & 40 \\
\hline \multicolumn{2}{|c|}{ 合計 } & 918 & $446(49 \%)$ & $416(45 \%)$ \\
\hline
\end{tabular}

者に対して居住者の紹介を依頼し，各業者を通じて調㚗用 紙を配布した。調査の対象とする地域跑主に東北地方で あるが，比較のために北海道，北陸地方などの地域も含め た。なお，各業者に住宅の紹介を依頼する際には高断熱高 気密住宅の条件として，1)断熱気密化された住戸，2)全室 暖房可能な住宅，3)計画換気がなされた住宅，4)入居後 1 年以上経過している住宅，の 4 条件を提示した非。

アンケート調查の内容は, 吉野による居住睘境の構成要 素》に従い，表 1 に示すように，各要素について把握できる ように設問を設けた。また，対象住戸での問題点を把握す るために, 結露, 室内空気, 家族の健康, 室内の音などに 関する設問を設けた。アンケート調查は冬期と夏期に分け て行い, 1993 年の 9 月と 1994 年 2 月にそれぞれ行った。

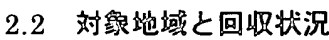

表 2 に調查の対象地域と回収状況を示す。対象地域の分 類に関しては，単純に都道府県別に分類している。回収数 は夏期と冬期とで多少異なっているものの，全体の回収率 は冬期で $49 \%$ ，夏期で $45 \%$ であった。

\section{3 調盗结鼠}

図 1 にアンケート調疽の集計結果を示す。 (1)住宅の特往

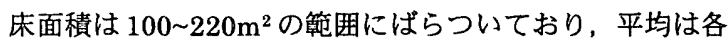
地域とも $160 \mathrm{~m}^{2}$ 前後である。とくに地域的な特徵は見られ ないが， $200 \mathrm{~m}^{2}$ 以上の規模の大きい住宅が北海道を除く各 地域に含まれている。次に，暖房設備は，「石油セントラル 式暖房」と「石油 $\mathrm{FF}$ 式煖房」が多い。また，冷房設備の保 有率は東北地方全体で $50 \%$ であり，南の地域ほど保有率が 高くなる傾向が見られ，北海道の保有率は $10 \%$ 程度と小さ
い。換気方式は,「給排気ともセントラル」が多いが、「排気のみセントラ ル」が福島県で特に多く見られる。また, 青森県では「各室個別の機械換 気」が半分以上占めている。住宅特性については，地域性が明確に表れる 場合は少なく, むしろ各都道府県における工務店・施工業者生4の片寄りが 宅特性に直接反映していると考えられる。

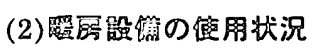

連続全室暖房を行っている割合は東北地方で $50 \%$ 前後である。また，連 続暧房しない理由として「䁔房費の節約」「「家を空けるため」よりも、「䁔 房する必要なく䁔かい」ことを理由に挙げている割合が高い。これは，住 宅の断熱気密化により熱の損失が小さくなっていることに起因するものと 推察される。

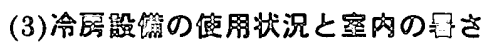

冷房設備を「常に用いる」住宅は少なく「時々用いる」場合が多い。冷 房設備を使用しない理由として，「電気代の節約」や「体に良くないから」 を理由に挙げている回答は少なく,「空の開放で十分」との回答がほとんど であり，東北地方全体では約 $60 \%$ を占めている。また，「日射遮蔽による 勃果」や「屛風機の使用」を理由に挙げている回答も見られる。

居住者が感じている夏期の室内器境に関する問題点として，「室内の暑 さ」を举げている自由記述形式の回答には、「熱がこもる」、「熱が逃げにく い」、「冷房がないと過ごせない」との指摘が見られたが，これらの指摘は 全体の $20 \%$ 程度であった。しかし，この結果には調㚗時期の夏期が冷夏で あったこと施や，回答形式を選択式にしなかったことなども影缺している と考えられたため，再度，1995 年 8 月に暑さに対する簡単なアンケート調

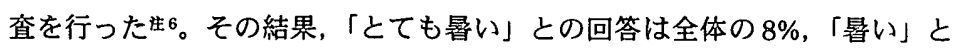
の回答は $29 \%$ となっている。暑いとの回答に対する理由として，「日射遮 蔽ができない」(17.4\%)，「熱が逃げにくい」(22.2\%)などが挙げられてい る。高断熱高気密住宅では「日射遮做」が不十分であったり,「排熱の工夫」 がなされていない場合には室温の上昇を招きやすいことが指摘できる。

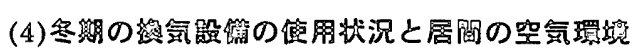

換気設備は「常に邅転」させる割合が全体的に高く, 東北地方全体では

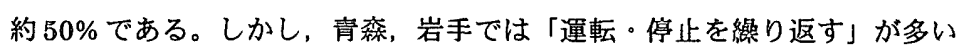
が, これは, 換気設備が各室個別の機械換気であることが理由の一つとし て考元られる。また，図には示していないが，換気設備を停止させる場合 は「外出するとき」、「就寝するとき」という回答が多く見られた。

居間の空気の污れは、「台所で調理しているとき」や「喫煙者がいるとき」 に空気の污れを感じている。空気の污れを感じている住宅の割合は，北海 道では $5 \%$ 未満であり，東北地方では青森と岩手で $40 \sim 45 \%$ と多く，その 他の地域では $30 \%$ 以下である。

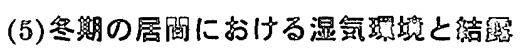

居間の湿気環境は，以前住んでいた住宅と比べて「乾嬠気哧になった」 と回答した居住者が東北地方で $45 \%$ を占めている。

居間の結䜿は, 北海道及び查北地方においてはほとんど見られないが, その他の地域では約 $40 \%$ の住宅で結露が生じていると回答している。

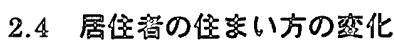

図2, 图 3 は，高断熱高気密住宅に移って冬期及び夏期の住まい方にどの ような変化があったかを示している。まず，図 2 を見ると，冬期において は「朝の起床が楽になった」、「夜のトイレが億劫でなくなった」と答えて いる居住者が多く，全体の $60 \%$ 前後を占めている。また，割合が少ないも のの,「褀足で過ごすようになった」，「子供や高龄者の室内での活動筑囲が 広がった」という指摘も見られる。これらの結果より，住宅の断熱気密化 によって冬期の温熱想境の向上が実現されていることが把握できる。 


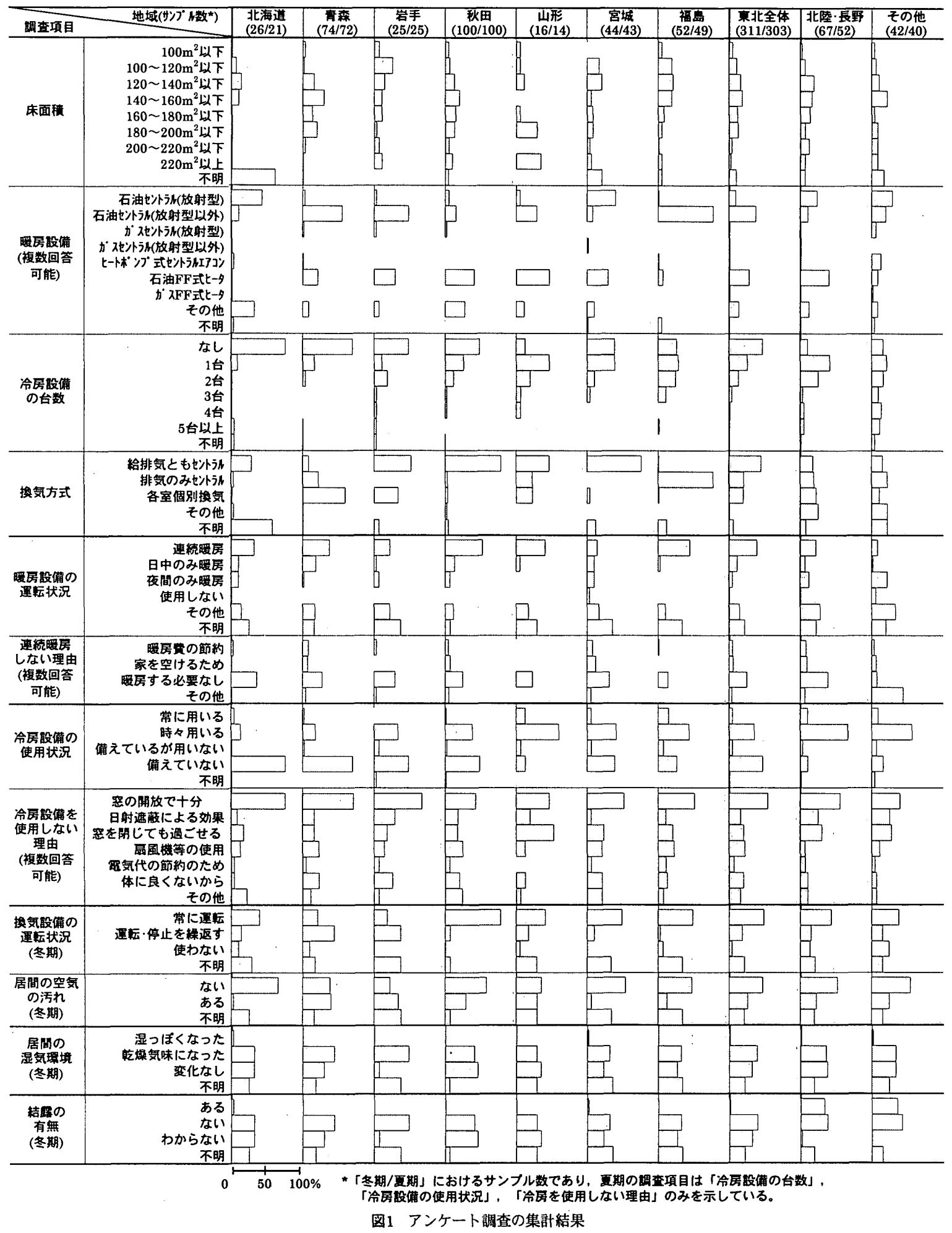

次に，図 3 を見ると，「冷房が不必要になった」と答えている居住者が 最も多く $40 \%$ 前後を占め, 次いで，「通風に気を使う」，「日射遮蔽に気を 使う」が挙げられる。この結果は，日射遮蔽や通風に気を付ければ，室温 上昇を抑えられることを示唆している。

\section{5 居住者の健康に関する変化}

入居後の健康上の変化に対する意見生7は，冬期の場合がほとんどであ り， $40 \%$ の居住者が良い変化があった， $15 \%$ が悪い変化があったと回答 している。入居後の健康上の良い変化, 悪い変化の内容を, 図 4 , 図 5 に
示す。図 4 より，良い変化として，「かぜをひかなくなった」 が特に多く、「神経痛, 腰痛, 肩こりがなくなった」がこれ に続く。これらの変化は，住宅の断熱気密化にともない温熱 環境が向上し，居住者の生理的なストレスが小さくなったこ とがその理由として考えられる。また，わずかではあるが 「アトピー性竟炎が良くなった」,「アトピーの症状が軽く なったとの指摘が見られる。一方，悪い変化については，図 5 より、「乾燥肌になった」及び「喉の具合が悪くなった」と 


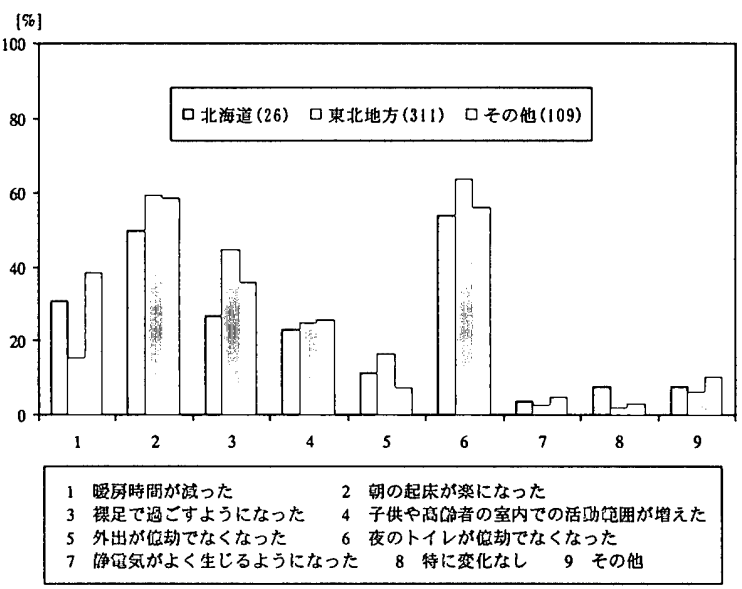

園2 冬期における住まい方の変化

の指摘が多く，「アトピー性皮虞炎が悪化した」という指摘も見られる。

\section{3 实測調盗}

\section{1 対象住宅の䈣㱯}

対象住宅は，先に示したアンケート調㚗の調㚗対象住宅において何らかの問題 点生8を指摘している住宅を選び，冬期と夏期に実椡調查を行った。測定对象住宅 は，仙台市及び盛岡市に建設されている断熱気密化住宅 16 戸(各都市 8 戸)である。

表 3 に調㚗対象住宅の概要を示す。No.1 8 が仙台市内の住宅, No.9 16 が盛岡 市内の住宅である。いずれも䇋工後間もない住宅で，床面栍は，不明な住宅を除 くと， $130 \mathrm{~m}^{2}$ 以下が 5 戸，130 160 $\mathrm{m}^{2}$ 圭満が 3 戸， $160 \mathrm{~m}^{2}$ 以上が 6 戸に大きく 3 つに分けられる。断熱材は，いずれの住宅も，壁，床，天井すべてに施されてい るものの全体的に，天井の断熱より，壁や床の断熱が十分でない住宅がいくつか 見られる。また，空カラスは全ての住宅において複屇ガラスとなっている。暖房 設備は，仙台の No.7 の住宅を除いてすべて全室暖房可能な設備を保有している。

No.7の主要暖房設備は開放型ストーブである。この住宅は，他の住宅に比べて 断熱材の使用状況も十分とは言えない。開放型ストーブは, No.6 の住宅でも使わ れている。また, 仙台市内の住宅はすべて, 補助暖房器具としてこたつや電気ヒー ターなどを使用しているが，盛岡市内の住宅ではその割合が小さい。クーラーの 所有状況は，仙台が 2 戸，盛岡が 3 戸である。なお，各住宅とも，居室の換気には 機械換気設備の使用が可能である。

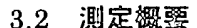

測定は，居間及び，北側に面した冬期に比較的室温の低い部屋の 2 室を対象と

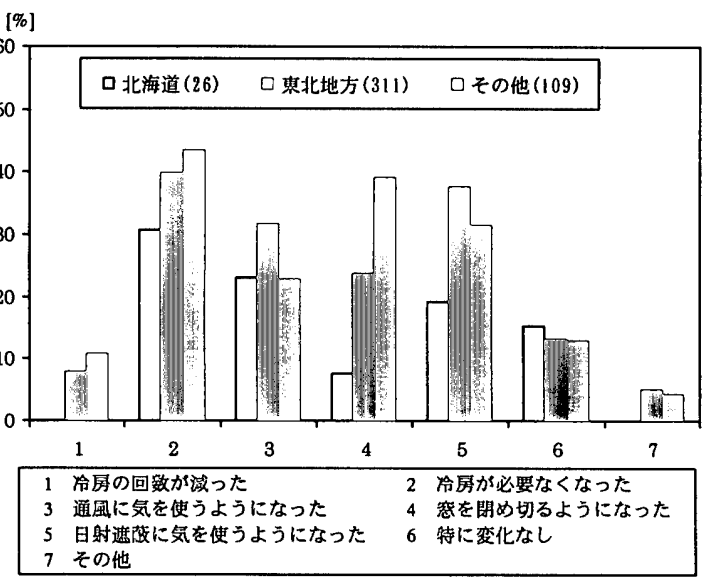

图3＼cjkstart夏期における住まい方の変化

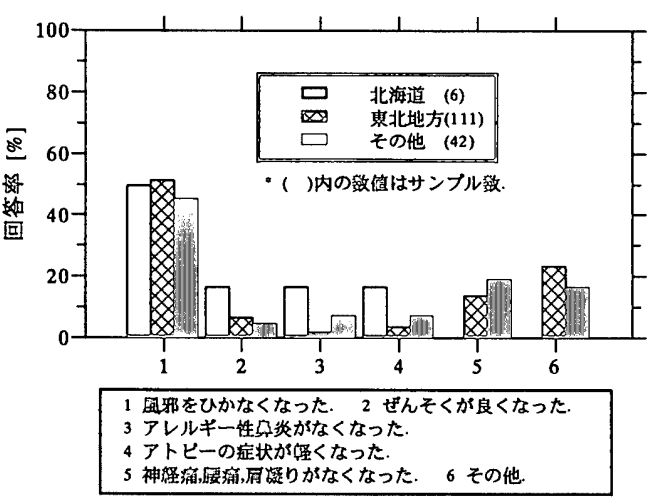

国4 健康上の良い変化

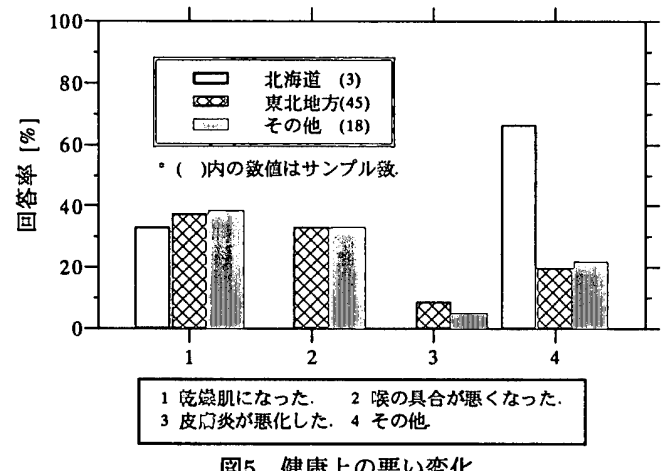

国5＼cjkstart健康上の悪い変化

言3 対鱼住宅の概要

\begin{tabular}{|c|c|c|c|c|c|c|c|c|c|}
\hline \multirow{2}{*}{ No. } & \multirow{2}{*}{$\begin{array}{l}\text { 竣工 } \\
\text { 年度 }\end{array}$} & \multirow{2}{*}{$\begin{array}{c}\text { 床面積 } \\
\left(\mathrm{m}^{2}\right)\end{array}$} & \multicolumn{3}{|c|}{ 欮熱材厚 $(\mathrm{mm}) /$ 阯熱材種穎 } & \multirow{2}{*}{ 暖房設備 } & \multirow{2}{*}{ 補助暖房器具 } & \multirow{2}{*}{$\begin{array}{c}\text { 冷房の } \\
\text { 有無 }\end{array}$} & \multirow{2}{*}{$\begin{array}{c}\text { 家族の } \\
\text { 人致 }\end{array}$} \\
\hline & & & 壁 & 床 & 天井 & & & & \\
\hline 1 & 1992 & 182 & $100 / \mathrm{GW}$ & $100+30^{\circ / 1} / S$ & $200 / \mathrm{GW}$ & ヒートポ ンプ式Iアコン & 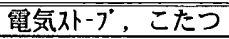 & 0 & 5 \\
\hline 2 & 1989 & 124 & $100 / \mathrm{GW}$ & $150 / \mathrm{GW}$ & $200 / \mathrm{GW}$ & 石油セントラル & こたつ & $x$ & 4 \\
\hline 3 & 1991 & 196 & $100 / \mathrm{GW}$ & $50+30^{21} / \mathrm{S}$ & $100 / \mathrm{GW}$ & 石油セントシ & 電気不-7 & 0 & 5 \\
\hline 4 & 1989 & 161 & $40 / U$ & $30 / \mathrm{U}$ & $40 / U$ & 石油セントラル & 電気不-7’ & $x$ & 3 \\
\hline 5 & 1990 & 117 & $40 / \mathrm{U}$ & $150 / \mathrm{GW}$ & $200 / \mathrm{GW}$ & 石油セントラル(温永 $n^{\circ}$ 祅) & こたつ & $x$ & 5 \\
\hline 6 & 1991 & 164 & $100 / \mathrm{GW}$ & $50+25^{\circ 1} / \mathrm{S}$ & $100 / \mathrm{GW}$ & 蓄熱式電気暧房 & 開放型石油不-7’ & $x$ & 4 \\
\hline 7 & 1989 & 155 & $25 / \mathrm{U}$ & $25 / \mathrm{U}$ & $50+30^{\circ 2} / \mathrm{GW}+\mathrm{U}$ & $x$ & 開放型石油不一-7* & $x$ & 5 \\
\hline 8 & 1992 & 106 & $40 / \mathrm{U}$ & $40 / \mathrm{S}$ & $100 / \mathrm{GW}$ & 石油FF式t-タ & 電気力ーペット & $x$ & 4 \\
\hline 9 & - & . & 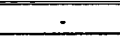 & . & 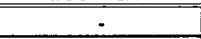 & 石油FF式t-夕 & $x$ & 0 & 6 \\
\hline 10 & 1992 & 151 & $50 / \mathrm{U}$ & $30+50^{11} / \mathrm{S}$ & $200 / \mathrm{GW}$ & 石油セントラ几(温水 $n^{\circ}$ 礼) & $x$ & O & 6 \\
\hline 11 & 1992 & 206 & $100 / U$ & $88 / \mathrm{U}$ & $200 / \mathrm{GW}$ & 石油セントラル(温永 $n^{\circ}$ 祅) & 電気力ーペッ卜 & 0 & 3 \\
\hline 12 & 1989 & 116 & $100 / \mathrm{U}$ & $100 / \mathrm{U}$ & $200 / \mathrm{GW}$ & 石油セシトうれ(温水 $n^{\circ}$ 礼) & $x$ & $x$ & 5 \\
\hline 13 & - & - & - & - & - & 石油FF式 $t-\xi$ & $x$ & $x$ & 4 \\
\hline 14 & 1992 & 137 & $50 / \mathrm{U}$ & $30+50^{21} / \mathrm{S}$ & $200 / \mathrm{GW}$ & 石油セントう川(温水版ネ) & $x$ & $x$ & 4 \\
\hline 15 & 1990 & 105 & $100 / \mathrm{U}$ & $88 / \mathrm{U}$ & $200 / \mathrm{GW}$ & 石油セントラ（温水 $n^{\circ}$ 祙) & $x$ & $x$ & 4 \\
\hline 16 & 1991 & 224 & $100 / \mathrm{U}$ & $88 / \mathrm{U}$ & $200 / \mathrm{GW}$ & 石油セント㞦(温水版礼) & $x$ & $x$ & 3 \\
\hline
\end{tabular}

No.1 8は仙台市内の住宅, No.9 16は盛岡市内の住宅, “1 基磁の断熱材厚, “2 屋根の断熱材厚 $\mathrm{GW}:$ グラスウール, U : ウレタンフォーム, $\mathrm{S}$ : スタイロフォーム 


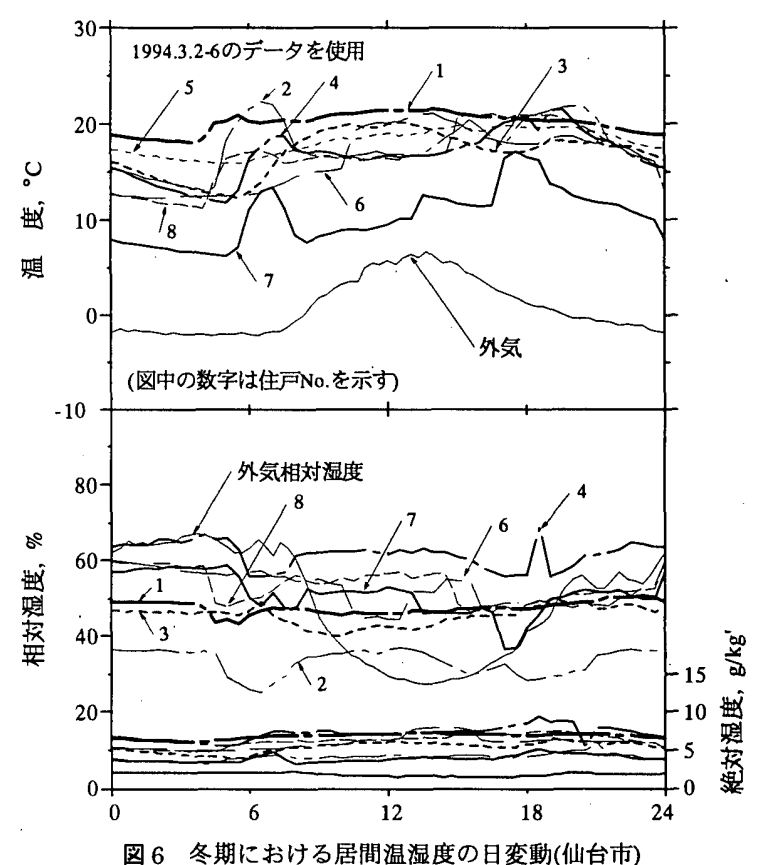

し，測温抵抗体及び小型データロガーを用いて行った。測定項目 は，1戸当たり 6 点(居間の床上 $5 \mathrm{~cm}$ の温度，床上 $1.1 \mathrm{~m}$ の温度・グ ローブ温度・湿度, 北侧室の床上 $1.1 \mathrm{~m}$ の温度, 湿度)である。デー 夕は 30 分平均したものを用い, 夕食後の室温の比較的安定した時 間帯を団らん時とする。外気温はすべての住戸にて測定できなかっ たため，仙台市では東北大学構内にて測定しているデー夕を，盛岡 市ではNo.10にて測定した值を用いた。冬期調查を 1994 年 2 月 3 月に，夏期調查を 1994 年の 8 月に行った。測定は，各住宅につい て最低 5 日間のデータが得られるように行った。

\section{3 測定結果}

\section{(1)冬期における温湿度変動}

図 6，7 に仙台市及び盛岡市内の断熱気密化住宅における，居間 の温湿度変動を示す。これらは，測定期間内の 5 日間のデータを時 刻別に平均し，1日の変動をモデル化している。この期間における

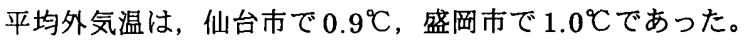

各住宅の室温は団らん時に $15 \sim 25^{\circ} \mathrm{C}$ の範囲で安定している。しか し，就寝時より明け方にかけて室温が低下する住宅と，低下せずに 比較的一定温度を維持している住宅が見られる。No.1，5，12，13， 15 は 24 時間暖房を行っている住宅であるが, これらの住宅の室温 変動は終日安定している。その他の住宅は間欠暖房を行っており， 就寝時には暖房を停止させている。特に, No.2，7では朝と夜のみ 暖房する住宅であるが，その住まい方の影響が測定結果に表れてい る。また, 測定では, 居間における床上 $5 \mathrm{~cm}$ での温度を測定した が，その結果を用いて上下温度差(林上 $5 \mathrm{~cm}$ と $1.1 \mathrm{~m}$ での温度差) を求めると，いずれの住宅も明け方平均, 団らん時平均及び日平均 は 0 4 ${ }^{\circ} \mathrm{C}$ 範囲におさまっていた。

相対湿度は，No.2，15で 40\%を下回る值を示しているが，ほと んどの住戸が 40 70\%の範囲で変動している站 9 。アンケート調査結 果では「空気の乾燥」を訴えている居住者が多く見られ，ここで示 したNo.10以外の住宅で「空気の乾燥」を訴えている。しかし，実 測で得られた湿度はそれほど低い值ではなく，アンケート調査の結 果とは必ずしも対応していない。

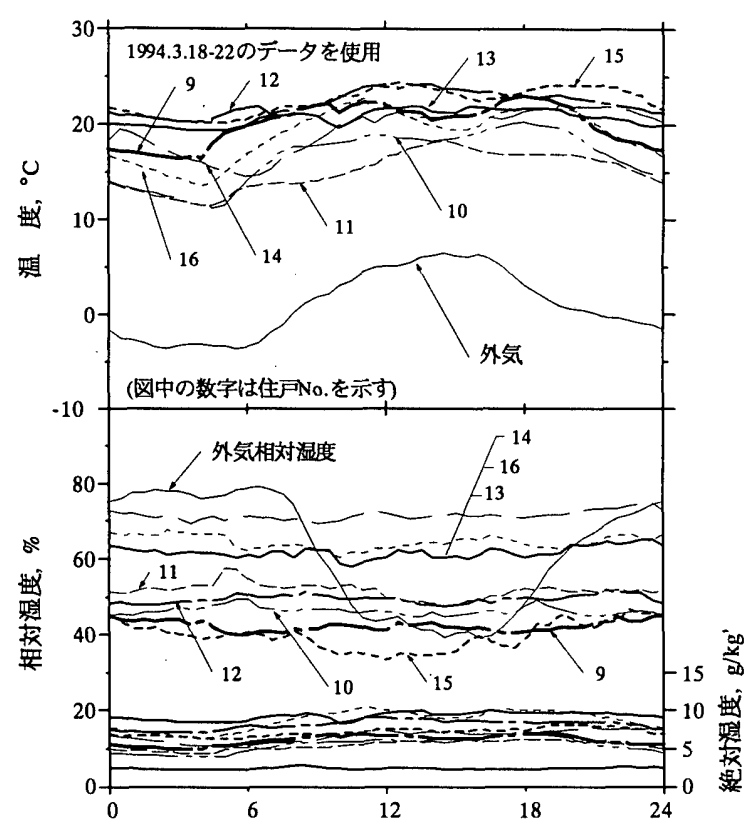

图 7 冬期における居間温湿度の日変動(盛岡市)

\section{(2)夏期における温湿度变動}

図 8 に盛岡市内の住宅(No.9,No.11 及びNo.14 を除く合計 5 戸 を対象)における居間の温湿度変動䅉10を示す。調查した年の夏期 は, 平年より気温が高く，仙台市及び盛岡市内とも 8 月の気温は平 年より $2 \sim 3{ }^{\circ} \mathrm{C}$ 高い。対象期間の外気温は盛岡市で $27.0^{\circ} \mathrm{C}$ であった。 室温は，終日外気温よりも高い住宅が多く, 夜間でも室温は低下 せずに，6 8${ }^{\circ} \mathrm{C}$ 室内外温度差がある。これは，日中には窓を開放 し通風を行うが夜間には空を閒鎖するためと考えられ，空の閒鎖に より外気温が低下しても室内における熱の流出が抑えられている。 また，No.10では冷房を備えているが使用しておらず，室温は外気 温より高い。測定期間中の外気温の変動を見ると，明け方の温度が $21 \sim 24^{\circ} \mathrm{C}$ まで低下しているため, 明け方の冷気をうまく室内に取り 入れれば，日中の室温上昇は比較的おさえられる可能性があり，例 えば，夜間換気を行うことで現状をかなり改善できると考えられ る。また, 室内相対湿度は, 各住戸とも $70 \%$ 前後で変動している。 3.4 明け方・団らん時における居間の;温湿度状態

図 9 は，測定期間中の居間における温湿度の状態を，明け方平均 及び団らん時平均ごとにプロットしたものである。各住宅で団らん 時と明け方の温湿度状態は, 相対证度差よりも室温差の方が大きい ことがわかる。

アンケート調査で対象とした住宅の $45 \%$ が，断熱気密住宅に住 むようになって空気の乾嬠を感じるようになったと訴えている。そ のうち，乾燥により家族の健康に何らかの被害(のどの痛み，乾燥 肌など)を被っていると回答した居住者が多く見られた。今回測定 した住宅のうち, No.2, 13, 14 が，乾燥による被害を感じている住 宅である。具体的には，「起床時に喉がいがらっぽい」(No.2)、「乾 燥しすぎで喉が痛い」(No.13，14)，「かぜをひきやすくなった」 (No.14)，「乾燥肌が悪化した」(No.14)などの居住者の意見が得ら れた。測定結果と比較すると，No.2では全体的に湿度が低く，明 け方の相対湿度が $30 \%$ を下回っており居住者の意見と符合する。 しかし，No.13 の測定結果を見るとそれほど乾燥しているとは思え ない" 11 。以上のことから，室内空気の乾喍を感じている住宅におい 
て湿度が特に低い訳ではなく，居住者の乾旟感は必ずしも低 湿度の影㸷ではないことが示唆される。

3.5 铻往の位完との比㵝

測定対象住宅の冬期における温熱睘境を既往のデータ8)と 比較することにより，熱環境の特徴を明らかにする。ここで は，冬期 5 日間の測定データに基づき団らん時を 19 時から 22 時と定義し，団らん時における各温度の平均值を用いて 比較する。また, 図 10, 図 11 に示す各グループの属性は次 のようになる。 $\mathrm{A}$ :東北地方主要 8 都市の公社分譲住宅(78 戸, 1968 年 1979 年建設), B:山形県の莀村部の住宅(30 戸，1978 年以前建設)， C:岩手県沢内村の住宅(9戸，1戸 を除いて 1970 年 1981 年建設)，D:仙台市近郊で断熱気密 性能の比較的高いストーブ暖房の住宅(7戸，1981 年 1984 年建設), E: 仙台市近郊で断熱気密性能の比較的高い床暖房 の住宅 $(6$ 戸, 1982 年 1984 年建設), $\mathrm{F}:$ 仙台市近郊の鉄筋 コンクリートの集合住宅(9戸，1964 年 1971 年建設), G:

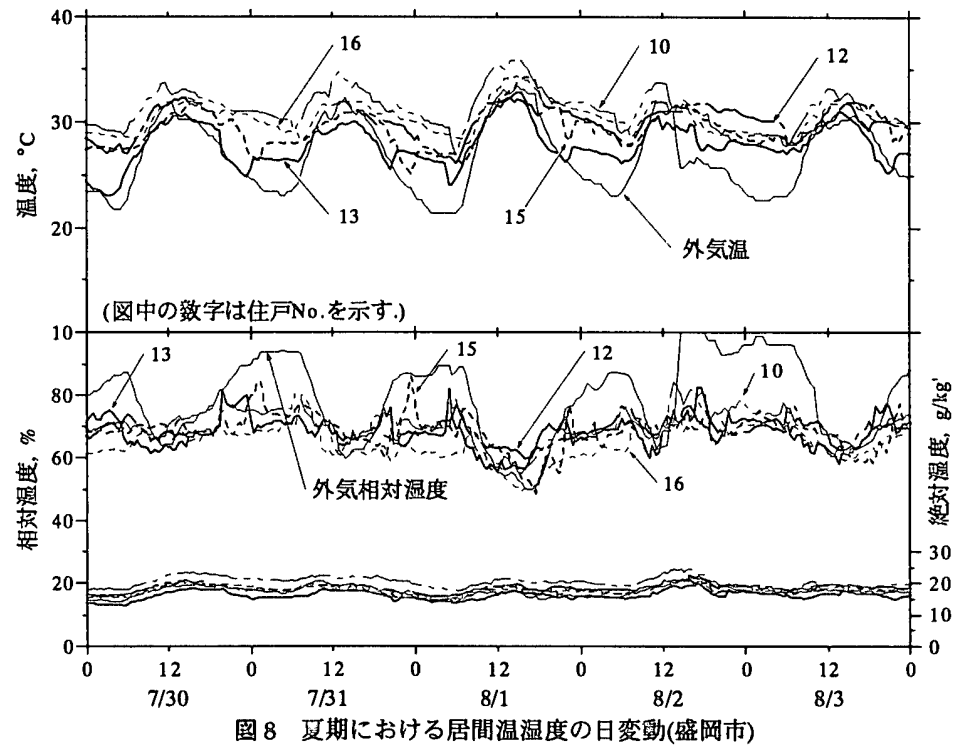
仙台市及び盛岡市の阯熱気密化住宅(16 戸，1989 年 1992 年建設).

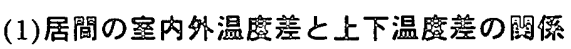

図 10 に，団らん時における居間の室内外温度差と上下温度差の 関係 ${ }^{8}$ を示す。ここで, 図中の $r$ 值を上下温度差倸效と定義し，上 下温度差(床上 $5 \mathrm{~cm}$ と $1.1 \mathrm{~m}$ の温度差) と室内外温度差の比をとる。 $r$ 值が小さいほど室内の温熱環境が快適に保たれる可能性が高い。 言い換えれば，温熱環境を快適に形成するための性能が高いことが 示される。

グループ G の調査対象住宅(No.1 No.16)の温熱器境は, No.7を 除くと，グループ E の高断熱・床暖房の住宅に近い水準にあり，室 内の温熱環境は住宅のシェルター性能及び設備性能の向上によりか なり良好となっていることがわかる。この結果は, アンケート調査 の冬期における温熱睘境に関する結果を反映するものと考えられ， 住宅の断熱気密化により居室の熱環境が向上していることが確認で

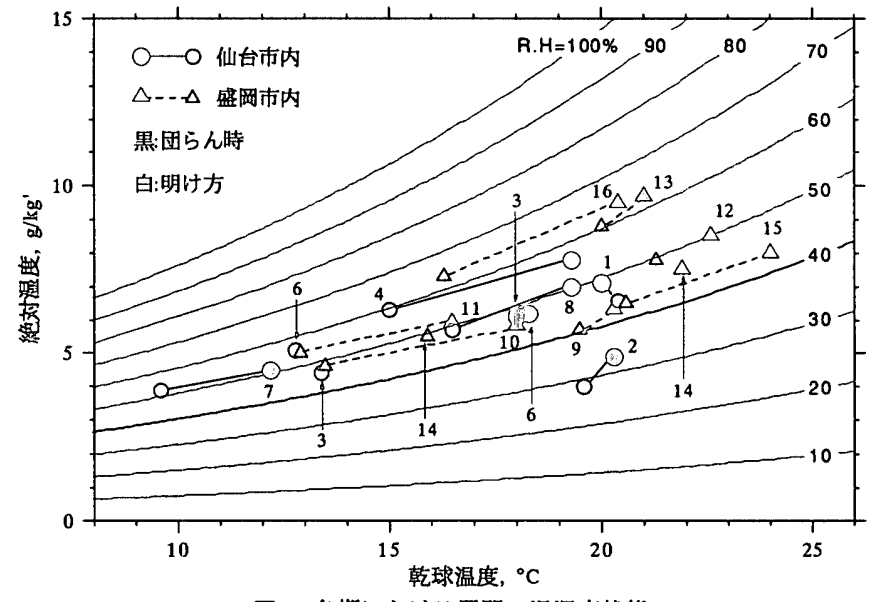

图9冬期における居閒の温湿度状態

きる。なお，No.7 は暖房システムがなく壁体の断熱材厚が小さいため，温熱環境 の水準が他の断熱気密化住宅と異なっていると思われる。また, No.7 を除いた住宅 の $r$ 值は, $0.0 \sim 1 / 8$ であるので, 外気温が $0^{\circ} \mathrm{C}$, 室温が $20^{\circ} \mathrm{C}$ のきの上下温度差は0 2.5 ○になるといえる。

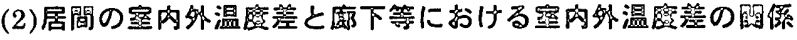

図 11 に，団らん時における居間の室内外温度差と一般に非暖房室と見なされる廊 下等における室内外温度差の関係 ${ }^{8)}$ を示す。今回, 調㚗対象住宅(No.1 No.16)の場 合は縌軸の值として, 住宅内において比較的温度が低いと考えられる北側居室の温度 を用いた。図中の $r$ 值を温度降下率とし，廊下あるいは便所(ク゚ループ $\mathrm{G}$ は北側居室 )の外気温基準温度と居間の外気温基準温度の比をとる。 $r$ 值が 1 に近いほど, 両室 の温度差が小さく住宅内で極端に温度が低いところが少ないことが示される。

グループ G の調䈏対象住宅(No.1 No.16)に注目すると $r$ 值が $0.7 \sim 1.2$ の筑囲にあ るため, 室間の温度差は小さいものと考えられる。図において, ク゚ループ Bやグルー プCに属する住宅は農村部の住宅であり，居間と廊下。便所との温度差が $20^{\circ} \mathrm{C}$ に達 する場合も見られ，これらの住宅においては室間の温度差が非常に大きいため生理的 なストレスが生じることにより血圧が上昇し，睬卒中の発症につながる恐れがあると の指摘が吉野ら のよってなされている。この観点からみれば, 高欮熱高気密住宅に おいては，は基本的に全室暖房であるため極端に温度が低い空間はないものと考えら れ，生理的なストレスがほとんどなく，居住者の健康に良い影留を与えていることが 明らかといえる。

(3)断熱氞密化住宅の茎内温䰻環㯇のグレート

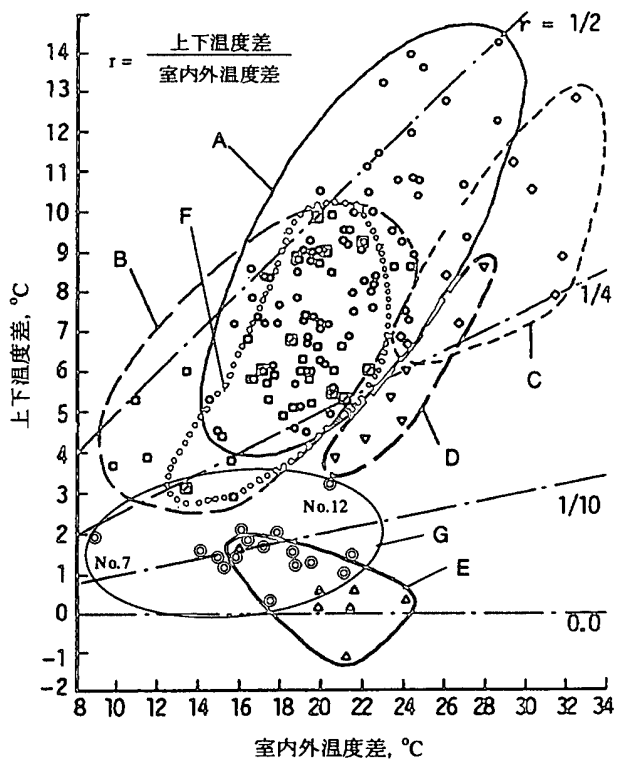

国10 団らん時の室内外温度差と上下温度差の閵係

断熱気密化住宅の室内熱環境がどの程度のレ ベルにあるかを把握するために，表 4 に示すよう に，室内温熱環境のグレード8)用いた。比較対 
象は山形県郡部に位置する住宅(グループ B)と高い断熱性能を持ち㦿暖房 を備えた住宅(グループ E)である。室内温熱瑻境を評価する指標として室 温, 上下温度差, グローブ温度などを取り上げ, 各項目ごとに 5 段階のグ レードを設けグレード 5 が最も評価が高くなる。表 4 を見ると, 断熱気密 化住宅 16 件における室内温熱睘境の各項目のグレードは山形県郡部の住宅 よりも高く，いずれも床暖房を備えた断熱住宅に近いことがわかり，住宅 の断熱気密化により室内温熱環境の質が向上していることが示される。ま た, 先に述べたように, 断熱気密化することの必要性として室内熱空気環 境の向上の観点から期待された，上下温度差の低隇及び輻射環境の向上が 実現されていることがわかる。

\section{4 おわりに}

断熱気密化により冬期において, 輻射環境の向上, 上下温度差の低減, 室間の温度差の低減, が実現されており, 温熱玮境は従来の住宅よりも良 好であることが示され，居住者の健康へ良い影響を与えている。一方，「空 気の乾燥」を訴える居住者が多く見られたものの, 室内湿度と乾燥感とは 必ずしも一致せず,「空気の乾燥」は低湿度が原因とはいえない可能性が 指摘できた。喉の痛みや目への刺激という症状は, 化学物質を使った新し い建材や接着剤などに使用されている，ホルムアルテヒドやVOC(揮発性 有機化合物)によって生じる場合が報告されており10), 居住者の乾燥感は これらの室内空気質によりもたらされている可能性があるといえ, 今後検 討すべき重要な課題である。また, 夏期の場合, 夜間に外気温が低下して も，空を閒鎖するため室温は低下しない住宅が多いが, 夜間換気を行うこ とで現状はかなり改善されるものと推察される。

\section{あとがき}

本研究の一部は 1993年度(財)住宅総合研究財団研究助成(東北地方における高断熱高 気密住宅の健康性と省エネルギー性から見た評佃によるものである。また, 本調査は, 日

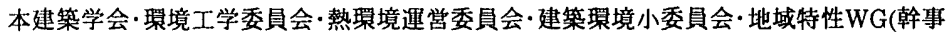
吉野 博, 赤林伸一, 石川善美, 内海康雄, 角舎辉典, 佐々木隆, 澤田紘次, 八町雅康, 松本真一, 三浦秀一，山岸明浩)及び住まいと㕩境東北フォーラム研究委員会(主査 吉野 博, 石川善美, 猪苗代裕, 内海康雄, 久慈るみ子, 鈴木 悟, 澤田紘次, 高島浩一郎, 二郷 精, 無江末次, 山本里見)が主体となって行っている研究の一舞である。アンケー 卜調查用紙の作成にあたっては、関保各位に貴重な意見を賜り，大変に参考になった。本 調查を行うにあたっては, 各工務店・施工業者の方々にこ協力頂いた。お世話になった方々 に,心から感謝の意を表する次第である。

\section{注}

1)平成4年に改正された「住宅に係るエネルギー使用の合理化に関する設計及び施工の指 針」(新省エネ法)において定められた性能を上回る住宅性能を有する, 良質な住宅を碓 保するために, 建設省が中心となって策定が検討されている誘導基準。

2)本墖文は既発表論文 1) 6)に加筆・修正を加㫕たものである。

3)「断熱気密化された住宅」という条件は㖟昧であるが, 結果として, 回答の得られた住 宅の断熱性能は, 各県とも新省エネルギー基準を满たすものが大半を占めており, 全体 の94\%が基準を满たしている。また, 気密性能について具体的な值は不明であるが, ほ とんどの住宅において気密化を行っている。

4)各都道府県ごとに1 8社であるが, 1 2 社が大半を占めている。

5)調查した年の 8 月の平均気温は, 盛岡市を例にとると $20.8^{\circ} \mathrm{C}$ あ゙り，平年よりも $2.4^{\circ} \mathrm{C}$ 低かった。ちなみに，翌年の1994年では $25.8^{\circ}$ Cであった。

6)アンケート調查用紙は先のアンケート調查により回答を得られた住宅446件に配布した。 回収は 230 件得られ，回收率は $52 \%$ である。

7)「こ家族の方の健康に何か変化がありましたか。」という質問に対する回答。

8)居住者の健康上の変化に対して,「悪い変化があった」と指摘している住宅を僘先的に選 んだ。その他の問題点としては, 夏の暑さや冬の乾燥が挙げられている。

9)北侧室の相対湿度は, ほとんどの住宅で30 60\%の篹囲で安定した変動を示している。 10)夏期における室内温湿度は, 冬期の結果を示したように平均化すると居住者の住まい 方の影響が顕著に現れてこないため図のように示した。

11)No.14では, 測定期間中に家を不在にすることが多く，実測結果が実際の居住状態を示 しているとはいえない。

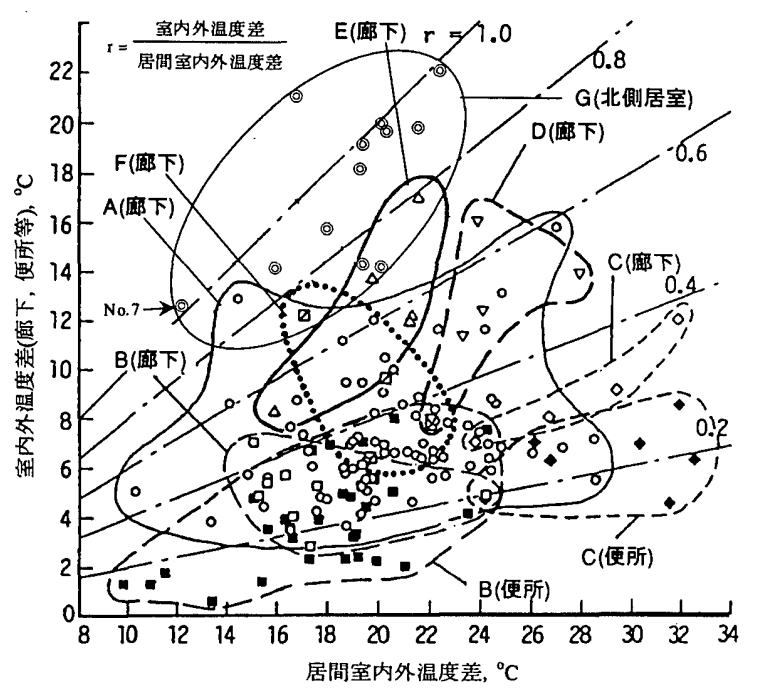

图11 居間の室内外温度差と廊下等における室内外温度差の関係

表4 室内温熱瑟境のグレードと対象住宅の測定結果

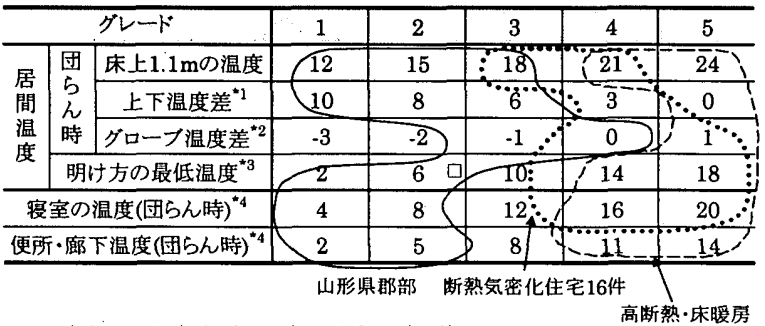

*1床上 $1 \mathrm{~m}$ の温度が $200^{\circ}$, 外気温が $0^{\circ} \mathrm{C}$ 時の值.

高断熱·床暧房

*2 グローブ温度と床上 $1 \mathrm{~m}$ 温度との差。

*3 外気温 $x^{\circ} 0$ C $の$ 時の值

*4 団らん時に, 居間の床上 $1 \mathrm{~m}$ の温度が $20^{\circ} \mathrm{C}$, 外気温が $0^{\circ} \mathrm{C}$ の時の值。

※ 口(No.7)は断熱気密化住宅16件からはずした.

\section{参考文献}

1)長谷川兼一, 吉野 博, 石川善美, 传藤博之:東北地方を中心とした 高断熱高気密住宅の健康性と省エネルギー性から見た評価(その1) 夏期におけるアンケート調查の概要と対象住戸の特性, 日本建筑学会 学術講演梗概集, 1994 年 9 月.

2)佐藤博之, 吉野 博, 石川善美, 長谷川兼一: 東北地方を中心とした 高断熱高気密住宅の健康性と省エネルギー性から見た評価(その2)夏 期のアンケート調查結果及び考察, 日本建筑学会学術講演梗概集, 1994 年 9 月.

3)吉野 博, 石川善美, 長谷川兼一: 東北地方における高断熱高気密住 宅の健康性と熱空気噮境 その1夏期の室内環境に関するアンケート 調查，第 18 回人間-生活環境系シンポジウム報告集，1994年 12 月. 4)吉野 博, 石川善美, 長谷川兼一: 東北地方における高断熱高気密住 宅の健康性と熱空気吅境 その2 冬期における温熱垻境の実測調查,

第18回人間.生活票境系シント゚ジウム報苔:集，1994年 12 月.

5)吉野 博, 石川善美, 長谷川兼一:東北地方における高断熱高気密住

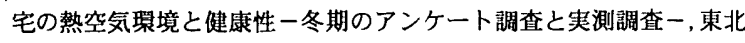
大学建築学報 第 34 号, 1995 年 3 月.

6)Ken-ichi Hasegawa and Hiroshi Yoshino: Investigation of indoor thermal environment and air quality in well-insulated and airtight houses in Tohoku district, Indoor Air '96, 1996.8.

7)吉野 博:寒冷地住宅の熱-空気瑟境設計一現状の問題点と今後の課 題一, 東北大学建築学報第 29 号, 1990 年 3 月.

8)長谷川房雄, 吉野博:東北地方の各種住宅における冬期の室温に関す る調查研究, 日本建筑学会計画系論文報告集,第371号, 1987年1月. 9)長谷川房雄, 吉野 博, 荒井宏朋, 岩崎 清, 赤林伸一, 菊田道宣: 脳卒中の発症と住瑟境との関係についての山形県郡部を対象とした調 查研究, 白本公滛衛生雑誌 第 32 巻 第 4 号, 1985 年 4 月.

10)岩下 剛, 赤坂 裕:カーペットから放たれる揮発性有機化合物質 が在室者の知覚空気質評価に及ほす影警に関する研究, 空気調和・街 生工学会学術講演会講演論文集, 1996年9月.

(1997年 7 月10日原稿受理，1997年12月 3 日採用決定） 